\title{
Geophysical and geological study on the West Qarchak fault and its implications in seismic hazard, Tehran, Northern Iran
}

\author{
1 Engineering Department of Kayson Company, Tehran, Iran. E-mail: bahmanesm@yahoo.com \\ 2 Department of Geology, Faculty of Basic Science, North Tehran Branch, Islamic Azad University, PO Box 19585-936, Tehran, Iran. \\ E-mail: m_almasian@hotmail.com \\ 3 International Institute of Earthquake Engineering and Seismology (IIEES), Tehran, Iran. E-mail: mehdi.zare.iran@gmail.com \\ 4 Department of Geology, Faculty of Science, Bu-Ali Sina University, Hamedan, Iran. E-mail: cheshme116@ gmail.com \\ 5 Head of the Kavir Sangan Company, Tehran, Iran.E-mail: alizadeh15@yahoo.com
}

The Alborz Range, northern Iran, is a chain of mountains along the southern side of the Caspian Sea. This mountain range shows strong tectonic activity with several destructive earthquakes in the past. The range is tectonically active, and the seismicity record shows both range-parallel left-lateral and thrust faulting. Tehran the capital of Iran and one of the largest cities in the world is located in the foothill of the Alborz Mountains, which is at risk of seismic hazard. This study is mainly focused on a scarp that passes by west of the Qarchak (a suburb in south east of Tehran) and therefore it is called the West Qarchak Fault. So, geological and geophysical surveying method was applied to study the West Qarchak Fault which is continuous and reaches to Pishva Fault in south east (with same trend) and crosses the Kahrizak Fault in the north west. In conclusion, it can be seen that apparently the geometry of the West Qarchak Fault is normal but the real mechanism is reverse (based on subsurface investigation). Morphologically, the Kahrizak Fault scarp has some similarity to the West Qarchak fault and it can be said that the geometry and mechanism of the Kahrizak Fault is same as the West Qarchak Fault, but requires a more detailed study.

\section{Introduction}

The Alborz mountain belt in northern Iran is an active region of complex crustal deformation located in the central portion of the Alpine-Himalayan orogenic system belt. The Alborz mountain range is $100 \mathrm{~km}$ wide and about $600 \mathrm{~km}$ long and trends roughly east-west, with many summits between 3,600 and 4,800 m elevation. Its presentday tectonics is characterized by high-angle faults that are mainly parallel to the mountain range, with the Damavand, a 5,671-m- elevation Quaternary volcano, in the centre of the belt. The Alborz mountain range is separated from the South Caspian Basin to the north by south-dipping faults (i.e. the Khazar and the North Alborz Reverse Faults; Fig.3) and from the Central Iran microplate to the south by north-dipping faults (i.e. the Mosha and the North Tehran faults; Fig.3). The seismicity in the Central Alborz range is distributed across the entire region and is quite shallow ( $<20 \mathrm{~km}$ depth) with dominant reverse or left-lateral strike-slip faults (Hedayati et al., 1976; Ashtari et al., 2005). According to geodetic measurements, the region accommodates approximately $5 \pm 2 \mathrm{~mm} /$ year of shortening and $4 \pm 2$ $\mathrm{mm} /$ year of left-lateral strike-slip motion (Vernant et al. 2004; Djamour, 2004), with a total tectonic shortening of about $30 \mathrm{~km}$ near Tehran since the early Pliocene (Allen et al., 2003; Ashtari et al., 2005).

On the basis of the historical and paleoseismological studies as well as geologic information, two main active fault zones have been considered responsible for occurrence of these seismic events: North Tehran-Mosha Fault in the north and the Rey-Kahrizak Fault in the

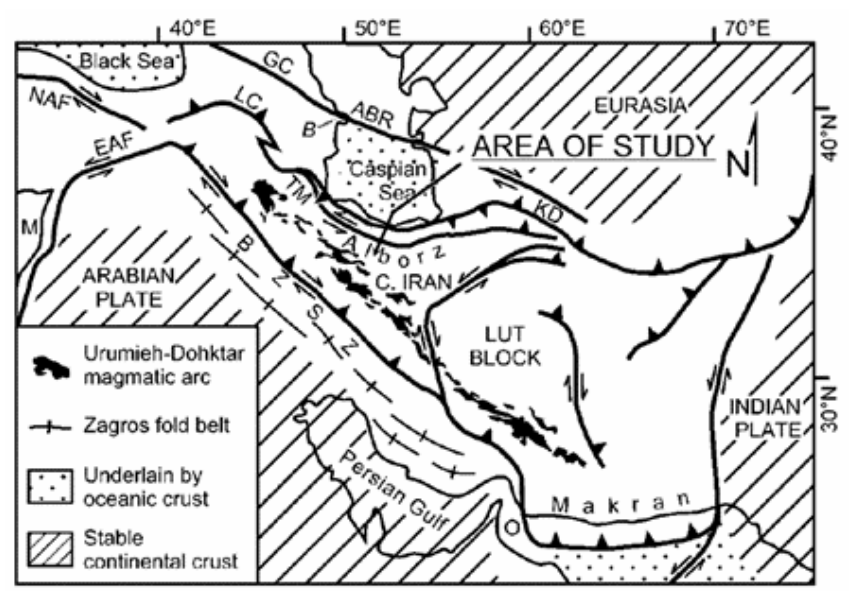

Figure 1. Tectonic map of Iran and surroundings (after Alavi, 1994; Berberian et al., 1999): ABR, Apsheron-Balkan ridge; B, Baku; BZSZ, Bitlis-Zagros suture zone; EAF, East Anatolian fault; GC, Greater Caucasus; KD, Kopet Dagh; LC, Lesser Caucasus; M, Mediterranean Sea; NAF, North Anatolian fault; O, Gulf of Oman; TM, Talesh Mountains. The southern side of the Caspian Sea and Alborz mountains can be seen. 


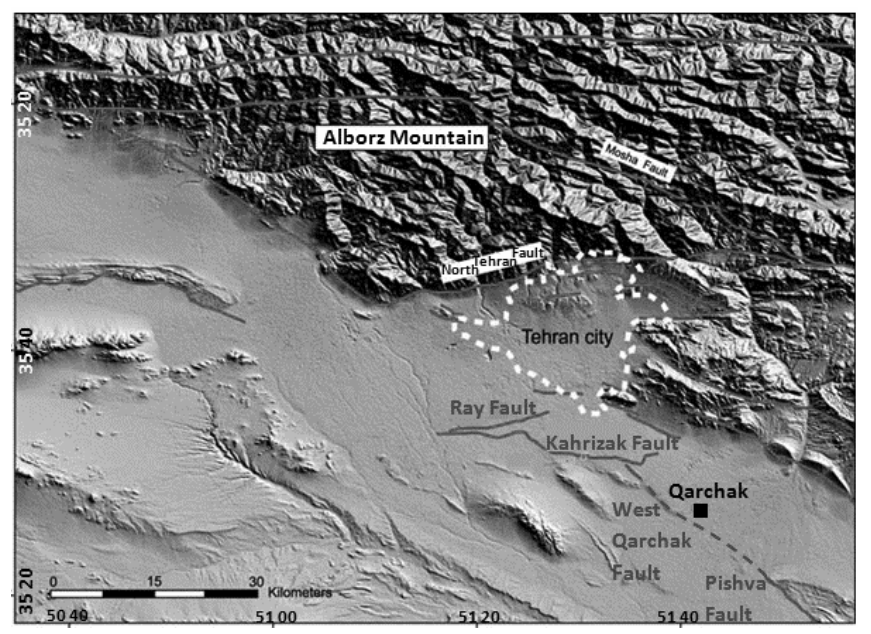

Figure 2- Alborz Range and its southern mountain front within Tehran region. Two main active fault zones: north Tehran-Mosha faults in the north and the Rey-Kahrizak faults in the south of Tehran city.

south of Tehran city (Fig. 2). Both zones show geologic and geomorphic evidences for late Quaternary-Holocene activity (Tchalenko et al., 1974; DeMartini et al., 1998; Ritz et al., 2006; Solaymani Azad et al., 2011; Ritz et al., 2012). The sense of movements across several exposures of the North Tehran and Mosha Faults are interpreted to indicate reverse faults dipping north with a component of left-lateral motion (Tchalenko et al., 1974; Berberian and Yeats, 2001; Bachmanov et al., 2004; Solaymani Azad et al., 2011). Among these historical earthquakes, the events of 855$856 \mathrm{AD}(\mathrm{M} \sim 7.1)$ and $1177 \mathrm{AD}(\mathrm{M} \sim 7.2)$ could be associated with the Kahrizak, North Rey and South Rey thrust faults, (Berberian et al., 1985), where paleoseismological evidence of the last event (in 1830 AD: M 7.1) found along Mosha-North Tehran Fault system within north of the region (Solaymani Azad et al., 2011). Seismic events of 885-886 AD and $1177 \mathrm{AD}$ were defined from the occurrence of three E-W trending fault located in the southern Tehran plain. The Kahrizak, South Rey and North Rey faulting are located within the southern plain of Tehran between the southern reliefs of Central Alborz mountains to the north and the western edge of Anti-Alborz. The 1384 AD destructive Rey region earthquake, has also been located on Pishva Fault (Nazari et al., 2010).

The South Rey and North Rey faults were first described by Pedrami (1981), who named them Valiabad and the Salehabad Faults. Berberian et al., (1985) renamed them to the South and North Rey faults, and also described for the first time the Kahrizak Fault. The geographical correlation between these scarps and the damaged areas associated with historical seismicity, Ambraseys and Melville (1982), Berberian et al.,(1993), then Berberian and Yeats $(1999,2001)$ proposed that, these faults could be defined as seismic sources of several strong historical events. However,
Nazari et al., (2010) considered that the Kahrizak, North Rey and South Rey scarps are horizontal scarps that follow contour lines matching ancient shorelines and they are not structural features. On the other hand, Azadi et al. (2010) believed that the Kahrizak scarp is a high angle normal fault dipping to south. Morphologically, the West Qarchak Fault has some similarity to the Kahrizak, North Rey and South Rey Faults. Studying West Qarchak Fault, could clarify the nature of the Kahrizak, North Rey and South Rey Faults. In order to define the geometry of West Qarchak Fault, field geological and geophysical investigations were carried out on this structure. During the course of geophysical investigations, electrical resistivity method (29 geo-electrical measurement) was applied based on the WennerSchlumberger array with lengths from 360 to $490 \mathrm{~m}$ in four sections (Profile A,B,C,D), across the West Qarchak Fault.

\section{Tectonic setting and stratigraphy}

In Tehran geological map with scale of 1:250000 (Haghipour et al., 1987, fig. 4) West Qarchak Fault is shown, as an inferred fault and its structural continuity with Pishva Fault is not displayed. West Qarchak Fault scarp starts from Southeast of Qarchak Town and reaches to the east section of the Kahrizak Fault with Northwest direction. It is located to the Southeast of the Kahrizak Fault and Northwest of the Pishva Fault. With reference to the Varamin geological map with scale of 1:100000, four geological units can be identified in the studied area.

Etb: Dacite breccia tuff with clastic to porphyroclastic texture.

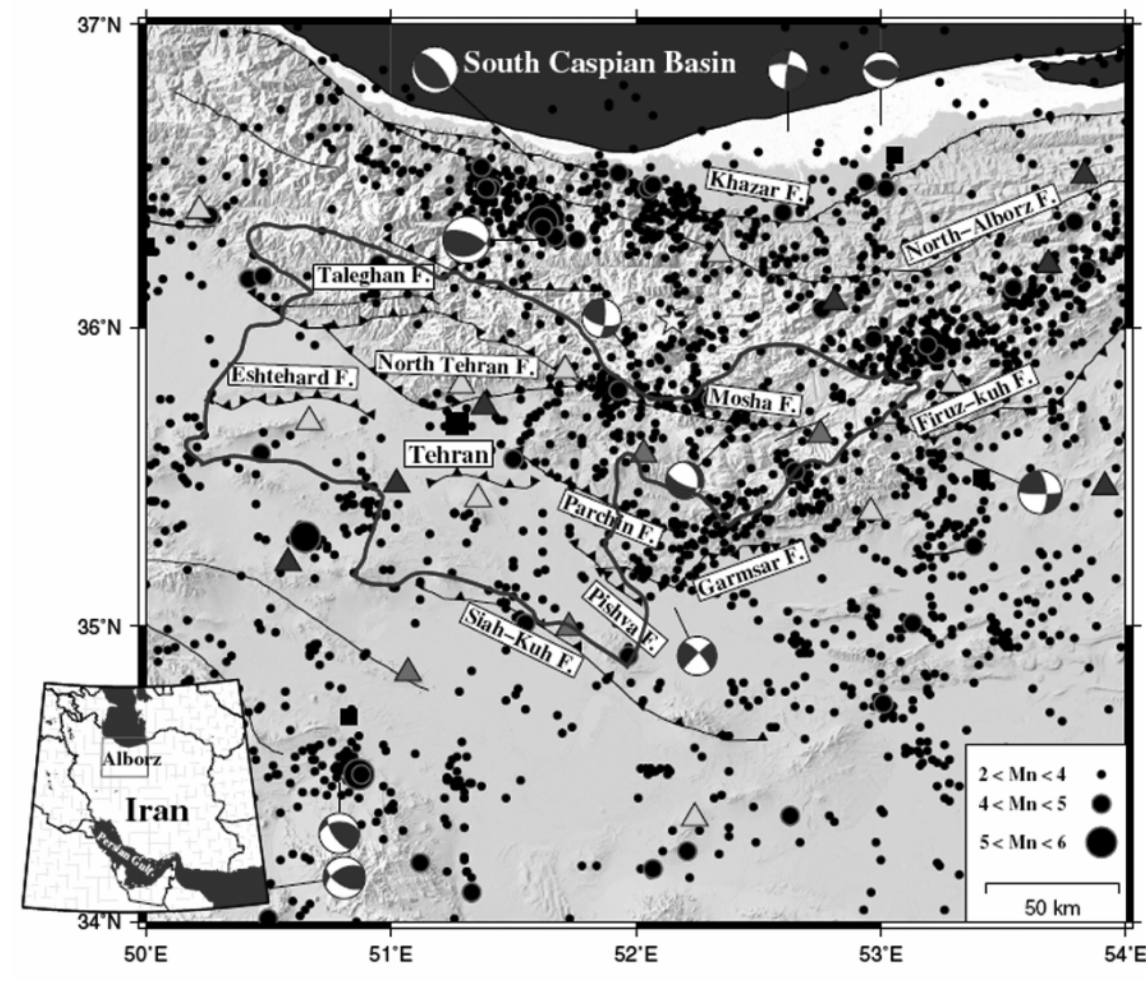

Figure 3. IGUT catalogue seismicity (black circles) for time window 1996-2010 and mapped faults (black lines) in the Central Alborz region. Only MN 2.0-5.9 earthquakes that are recorded by more than six stations and have an RMS less than 1 s are shown (2,690 events). The triangles indicate the seismic stations. The station's indications are fewer than 1000 to 5000. The Damavand volcano is marked by a star. Fault plane solutions of large events (Mw>5.0) are from the Global Centroid Moment Tensor Project catalogue (2012). 


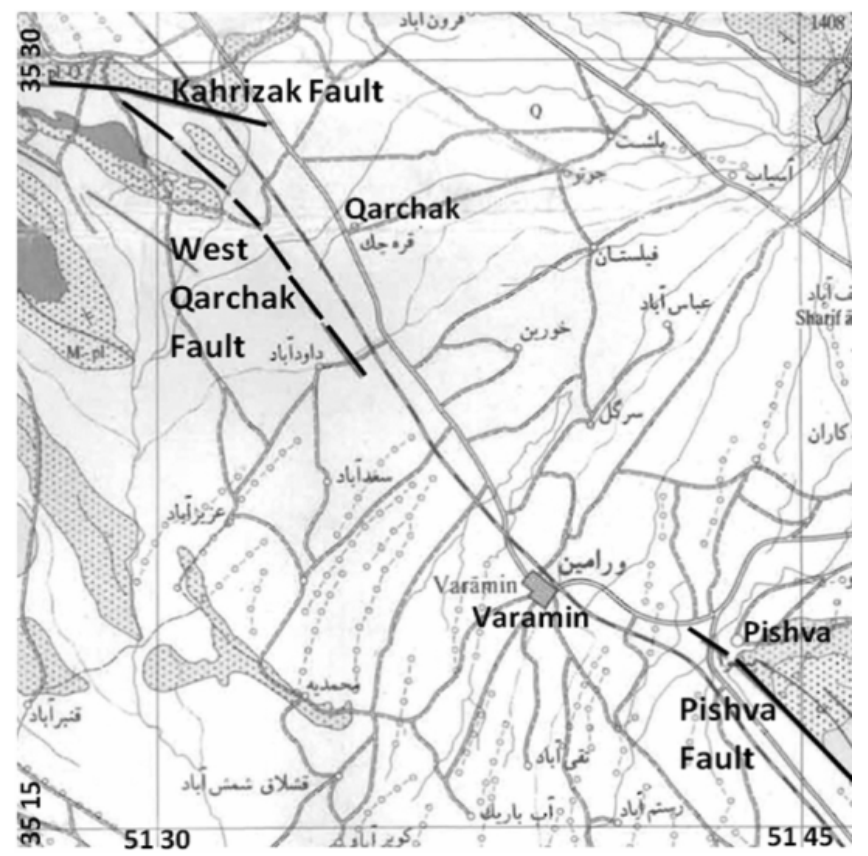

Figure 4. Tehran geological map (1:250000) which shows the West Qarchak fault as an inferred fault and is not shown the structural connection of that with the Pishva Fault.

This unit can be correlated to Karaj Formation (Eocene) and is considered as the bed rock.

Plc: Gray conglomerate with marly cement. This unit can be correlated with Hezardareh alluvial formation (Mio-Pliocene to Mid-Quaternary). Plc is covered by QP, and in some parts formed the body of scarp in studied area.

Qp: Alluvial plains deposit (fine grain moderately compacted sediments). This unit can be correlated with Kahrizak unit, Holocene.

Qt: Recent Quaternary coarse to fine grain fan deposits. The thickness and separation of this unit is limited in investigated area.
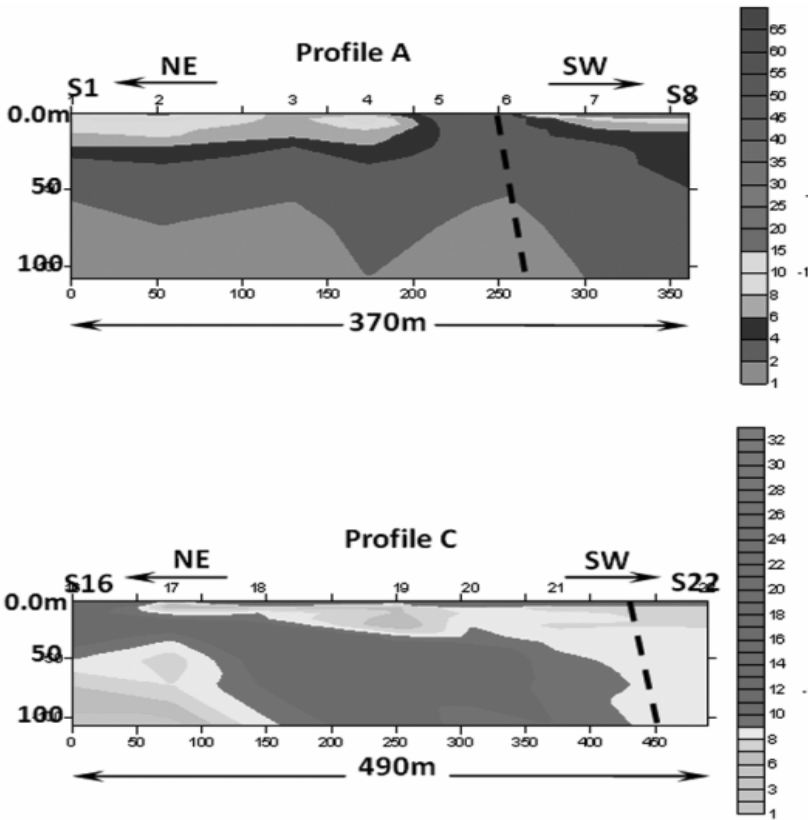

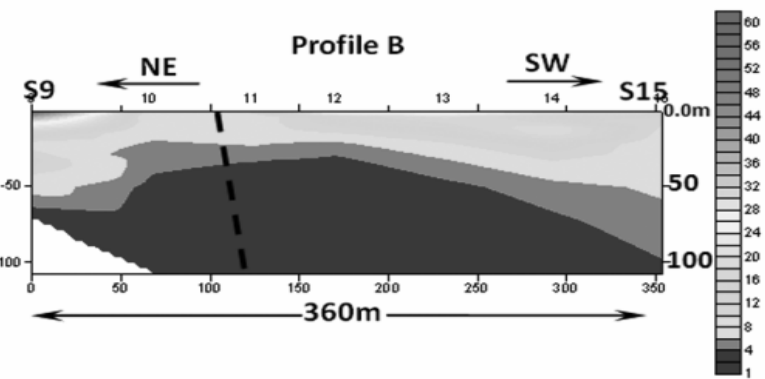

In Varamin geological map, this scarp is shown as the continuation of the Kahrizak Fault, which based on field observations and studies have shown it to be a separate structure that could reach to the Pishva Fault with the same trend and geometry. The height of this scarp is about 2 to $5 \mathrm{~m}$ and can be found easily in flat plain area as a topographic relief. There is an irrigation channel parallel to the scarp and as a result of that the depth of the water level in some part of footwall is shallow, and the road connecting Qarchak to the east of Kahrizak Fault passes through reedy areas or farm land. Plc Unit can be found as the key bed, in body of hanging wall, and mostly is covered by younger deposits, but in the footwall area this unit has disappeared completely. In other words Plc unit is cut off at scarp suddenly, so the West Qarchak Scarp must be considered as a structural feature. To understand the nature and mechanism of the West Qarchak Fault, some geo-electrical investigations were carried out.

\section{Geo-electrical investigations}

Integrated geophysical techniques have long been used to gain information about fault displacements or affects without physically excavating. So electrical resistivity method (29 geo-electrical measurement) were carried out based on Wenner-Schlumberger array with lengths between 360 to $490 \mathrm{~m}$ in four sections (Profiles A, B, C and D in Fig. 5), across the West Qarchak Fault. The length, position and direction of the profiles were chosen to cover the scarp completely. The distance between profile $\mathrm{A}$ and profile $\mathrm{D}$ is about 4 kilometres. The iso-resistivity profiles were illustrated to find out the geo-electrical condition of sub-surface layers. The depth of each profile is normally about a quarter of the total length (Alizadeh, H., 2010). Along all profiles the surface layers show higher electrical resistance as opposed to the sub-surface ones. At depth, the resistivity is decreased and displays a linear direction to the southwest. In another words, the pattern of resistivity shows southwest direction (Fig.5). In addition, to explain and discover the geological condition and displacement of sub-surface layers along the scarp, four sections were illustrated with regard to the geo-electrical tests information. As shown in Figure 6, an apparent vertical displacement can be found from Northeast to

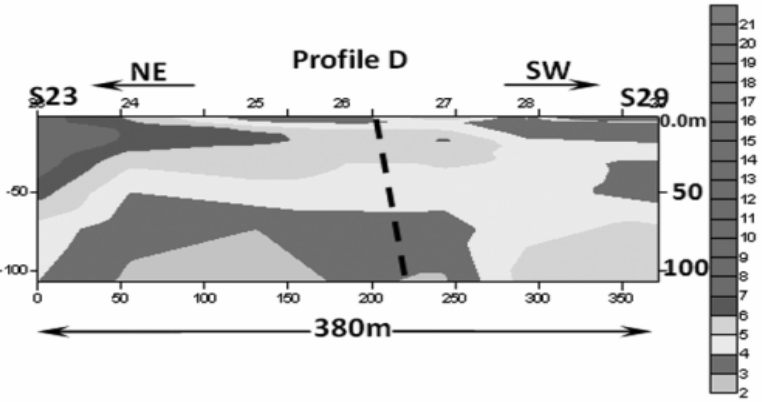

Figure 5. Iso-resistivity profiles $(A, B, C$ and $D)$ and apparent dip direction to south west. 

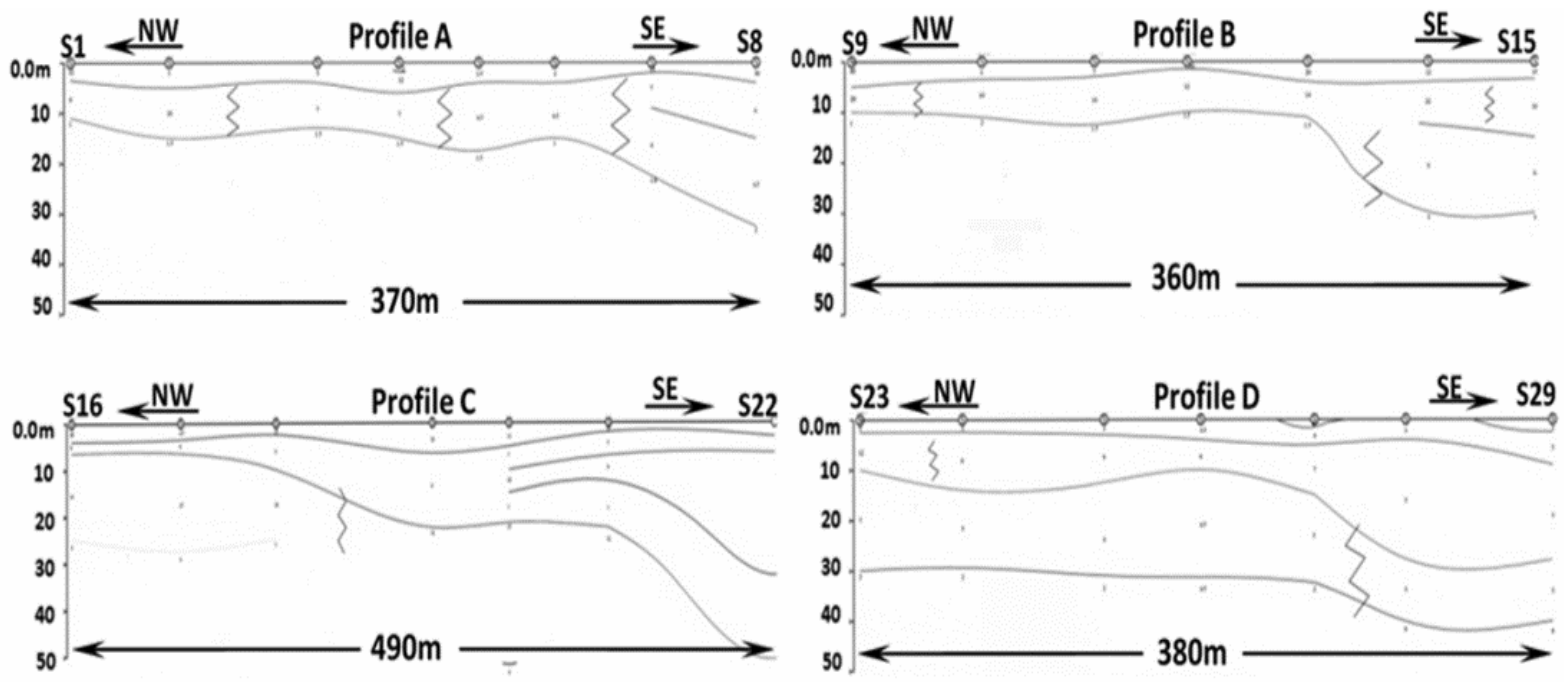

Figure 6. Electrical resistivity sections show about 25-30 total vertical displacement for WQF.

Southwest direction. However, it is difficult to correlate the stratigraphical units to geo-electric sections, but about 25 to $30 \mathrm{~m}$ total vertical displacement can be estimated along the West Qarchak Fault scarp in subsurface layers. Geoelectrical resistivity studies indicate that West Qarchak Fault shows apparent dip toward southwest, also geological units are settled in foothill zone of the scarp, so it seems the fault is a sub-vertical normal one like the Kahrizak Fault (Azadi et al., 2010) more to the northwest, but with regard to Active Fault Map of Tehran (Berberian et al., 1983, Fig.6) it must be considered that south area of Tehran is located in a compression zone. The north dipping, WNW-ESE main faults around the West Qarchak Fault are mapped as reverse faults, so with regard

51

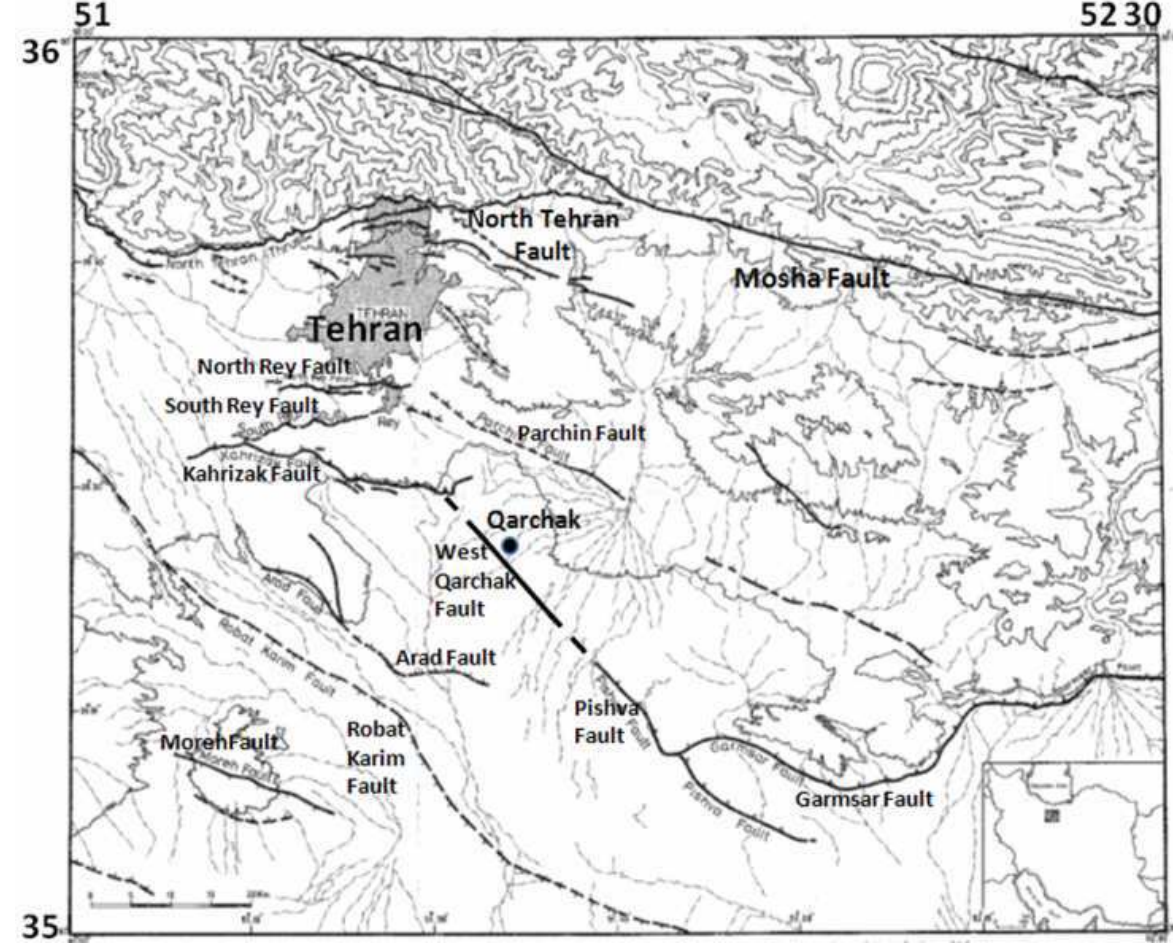

Figure 7 -Active fault map of the Tehran quadrangle (Berberian et al., 1983). West Qarchak Fault has been added to this map. to this condition it would be difficult to consider such normal south dipping normal fault as a direct continuation of Pishva Thrust Fault. (Fig. 7).

West Qarchak Fault seems as a sub-vertical reverse one dipping Northeast, but in surface layers the dip direction is changed to Southwest and it shows apparently normal geometry. Different examples can be found for this condition in the world, one of them is El-Asnam region earthquake (earthquake faulting) in Algeria (Philip et al., 1983). The El-Asnam earthquake Oct.10, 1980, shows complexity of surface deformation mechanism (Fig. 8). The principle mechanism consists of a NW-SE trending thrust fault, accompanied by left-lateral motion. In northern part of seismic zone some apparent normal geometrical motions could be seen over the reverse structures. Basically, the real mechanism is reverse in a compression region but on the surface, some structures show normal shape apparently (Philip et al., 1983).

In the present study, a segment of West Qarchak Fault with length of $4 \mathrm{~km}$ was investigated (Figs. 9 and 10) by geo-electrical method. It can be said that this fault reaches the Pishva Fault (Fig. 11) in southeast with same faulting characteristics and joints of Kahrizak Fault in Northwest (Fig. 12). According to Varamin geological map, West Qarchak Fault is considered as the Kahrizak Thrust fault, but it should be noted that West Qarchak Fault is indeed a separate structure, and could be considered as a continuation or segment of Pishva Fault. It must also be mentioned that no deformation in surface layers can be seen in geological units, and no historical or seismological evidence can be found in the studied area, so the West Qarchak Fault does not show any evidence but with regard to field geological and geophysical investigations, this scarp is a tectonic structure and not a shoreline feature. The scarp of the West Qrchak Fault reaches the scarp of 

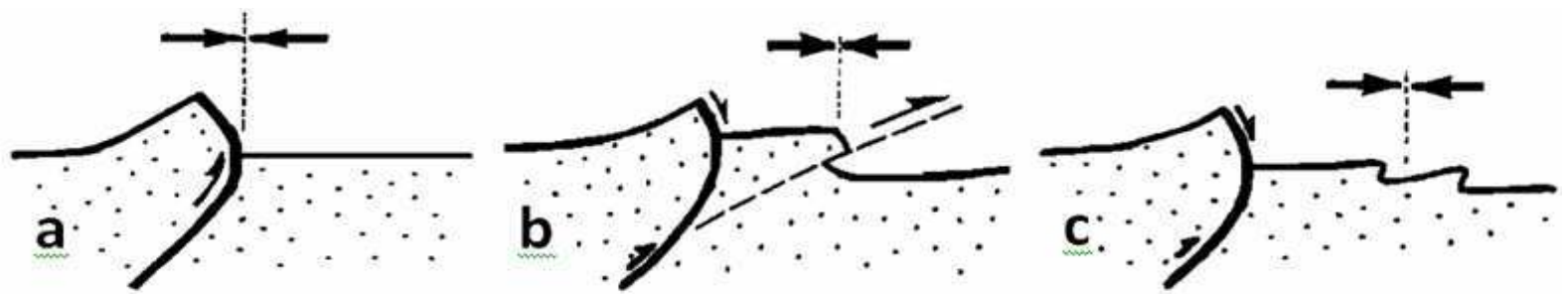

Figure 8. Simplified patterns ( $a, b$ and $c$ ) of apparent normal geometry in compression zone (North Africal, El Asnam region Earthquake). The fault mechanism is reverse but to the surface ground the dip direction changes and geometry seems to be normal apparently. Same features can be seen on the West Qarchak Fault. Geo-electrical tests shows apparent normal faulting but the mechanism is reverse.

Kahrizak Fault and both of them follow contour lines, and therefore they are not ancient shorelines. They are tectonic structures and have been covered by younger deposits that were transported by northern foothill flows within a shore region. As a result, the West Qarchak Fault is a separate tectonic structure and could be the continuation of the Pishva Fault. Also it is suggested that the Kahrizak Fault scarp has the same morphology of the West Qarchak Fault scarp, means the
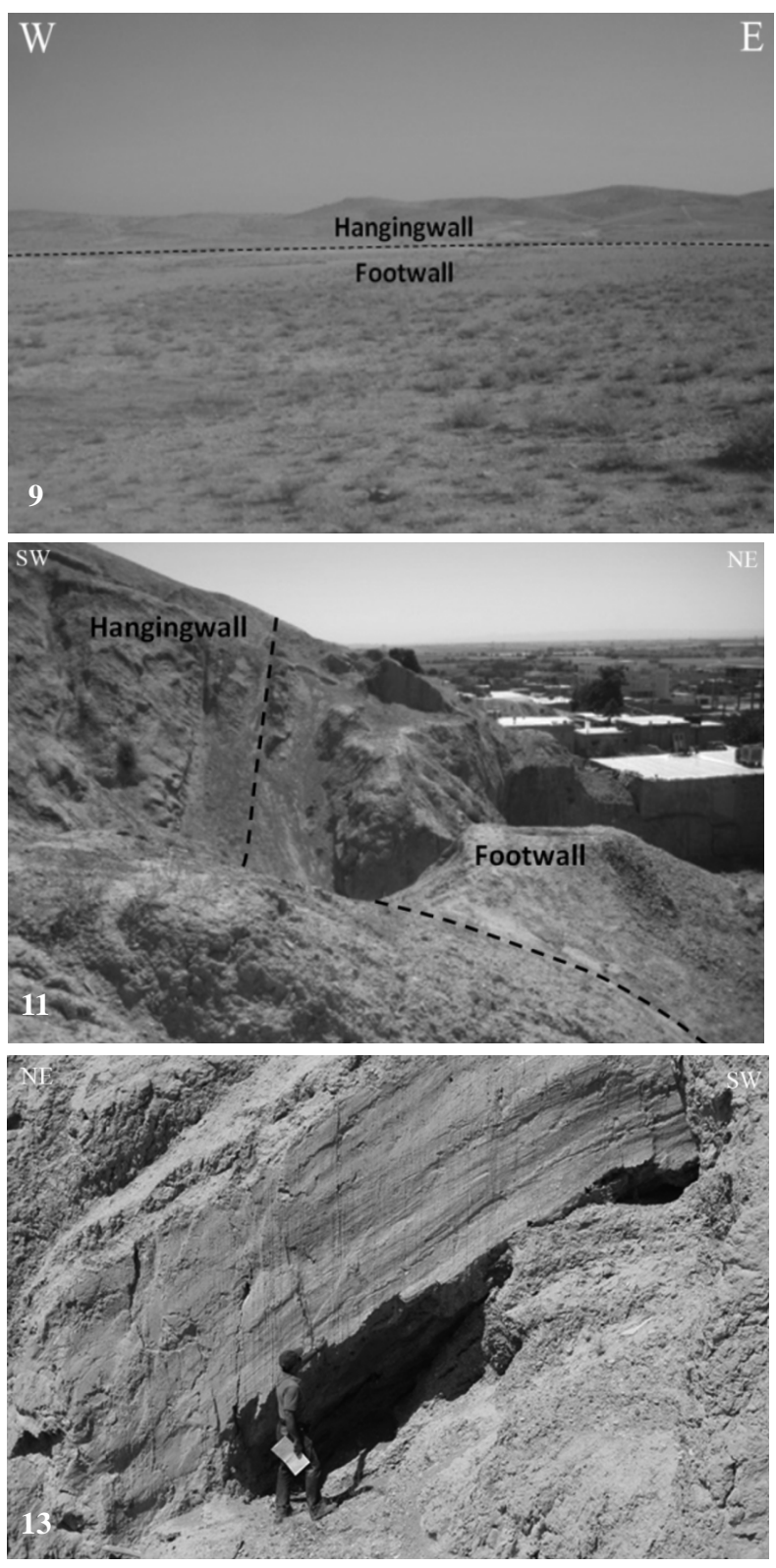

Kahrizak Fault could be a reverse structure shows normal geometry in surface layers in the same way as West Qarchak Fault mechanism.

\section{Conclusion}

The results of geological and geo-electrical investigations on this feature show a reverse fault (West Qarchak Fault) with apparent normal
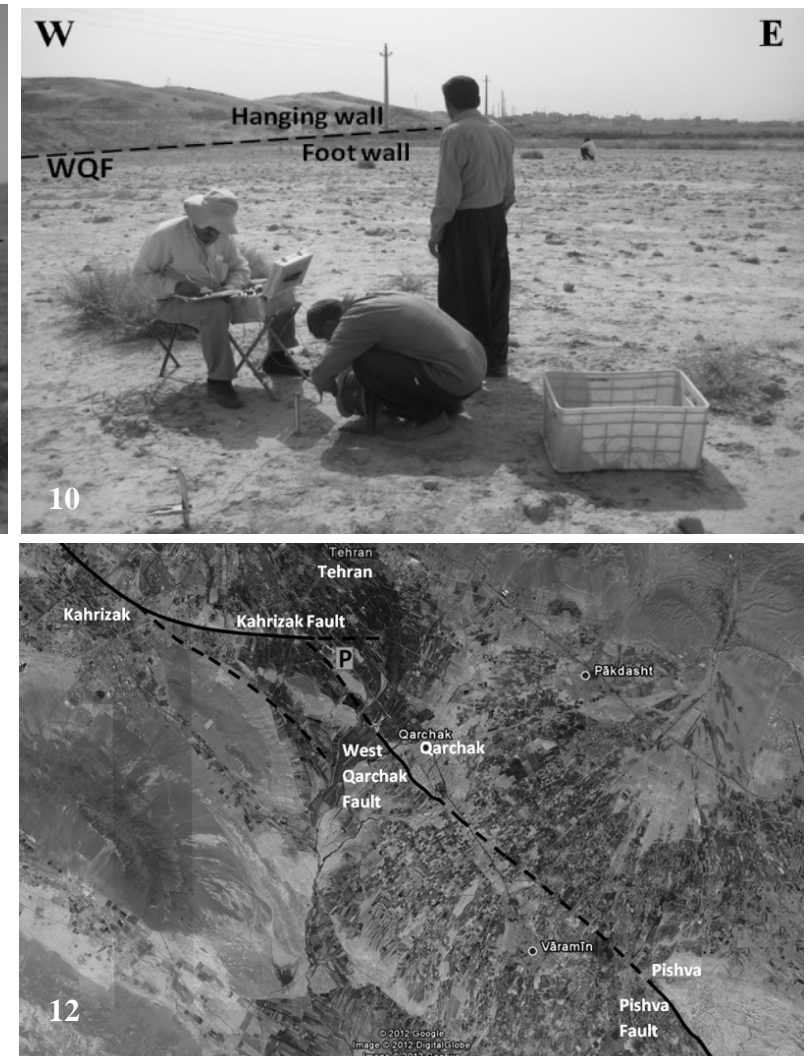

Figures 9 to 13. (9-10) West Qarchak Fault and its scarp in Northwest of the profile D (left), Geo-electrical tests in profile b, West Qarchak Fault (right). (11) The Pishva sub-vertical Reverse Fault in the Pishva Town (Strike: N135, Dip: 83 $N E)$.To the north this fault reaches to the West Qarchak Fault. (12) The continuation of the West Qarchak Fault reaches to the Pishva Fault with same trend Southeast, and also crosses with the Kahrizak Fault Northwest. (13) The scarp of the Pishva Fault in Pishva Town, 15 to $16 \mathrm{~km}$ Southeast of the West Qarchak Fault (studied area). The 1384 AD destructive Rey region earthquake, has been located on this fault (Nazari et al., 2010), but no evidence has been found on the West Qarchak Fault up to now. 
geometry is hidden under the West Qarchak Scarp. The scarp is a tectonic feature not just a shore line or morphologic one. The trend of the West Qarchak Fault is Northwest-Southeast and dips to Northeast. This fault crosses with the Kahrizak Fault to Northwest, reaches to the Pishva Fault to Southeast and it seems this structure is the continuation of the Pishva Fault. No paleo-seismologic evidence can be found on the West Qarchak Fault in studied area but the 1384 AD destructive Rey region earthquake, is located on the Pishva Fault by Nazari et al. (2010). From morphologic point of view, the West Qarchak Fault and the Kahrizak Fault have similar shapes, so it seems the Kahrizak Fault could also be a reveres fault, showing apparent normal geometry at the surface.

\section{Acknowledgements}

This study was carried out in the framework of Kayson Company project and was supported by this company completely. We are grateful to A. Aftasi, H. Kamarei and A.R. Inanlou, coordinators of this project. We also thank to S. Shahabi, M. Aryan, A. Ansari and P. Tajbakhsh for their help and fruitful discussions.

\section{References}

Alizadeh, H., 2010, Geo-Electrical study of West Qarchak region: Kavir Sang Ab Company, Kayson Company.

Allen, M.B., Ghassemi, M.R., Shahrabi, M., Qorashi, M., 2003, Accommodation of late Cenozoic oblique shortening in the Alborz range, northern Iran: Journal of Structural Geology, v. 25, pp. 659-672.

Allen, M., J. Jackson, R. Walker, 2004, Late Cenozoic reorganization of the Arabia-Eurasia collision and the comparison of short-term and longterm deformation rates: Tectonics, 23, TC2008, doi:10.1029/2003TC001530.

Ambraseys, N.N., Melville GP., 1982, A History of Persian Earthquakes: Cambridge University press, New York.

Azadi, A., Hessami, Kh., Javan-Doloei, 2004, Integrated geophysical methods for determining geometry of the Kahrizak Fault:Tehran, Natural Hazards DOI 10.1007/S11069-010-9506-9.

Axen Gary J., S. Lam Patrick, Grove M., Stockli DF. , Hassanzadeh J., 2001, Exhumation of the west-central Alborz Mountains, Iran, Caspian subsidence, and collision- related tectonics: Department of Earth and Space Sciences, University of California, Los Angeles, California 900951567, USA.

Berberian, M., Ghorashi, M., Arzhangravash B., Mohajer Ashjai A., 1985, Seismotectonic and Earthquake Fault Hazard Investigations in the Tehran Region (In Persian): Geological Survey of Iran.
Berberian, M., Ghorashi, M., Arzhangravash, B., Mohajer Ashjai, A., 1993, Seismotectonic and Earthquack-Fault Hazard Investigations in the Tehran Region: Geological Survey of Iran, Report No. 56.

Berberian M., and Yeats, R.S., 2001, Contribution of archeological data to studies of earthquake history in the Iranian Plateau: Journal of Structural Geology, v. 23, pp. 563-584.

Geological Survey of Iran (Haghipour), 1986, Tehran 1:250000 geological map.

Geological Survey of Iran (Sadeghi), 2003, Varamin 1:100000 geological map.

Hedayati, A., Brander, J.L., Berberian, M., 1976, Microearthquake survey of Tehran region, Iran: Seismological Society of America, v._. pp.

Maleki V. Hossein Shomali Z., Hatami MR., Pakzad M., Lomax A. , 2013. Earthquake relocation in the Central Alborz region of Iran using a nonlinear probabilistic method: Springer Science+Business Media Dordrecht.

Majidi Niri T., Nazari H., Ghorashi M., M. Talebian M., Kaveh Firooz A., 2010, First Records of 1384 AD Shahr-e-Rey's Historical Earthquake on Pishva Fault based on Paleoseismology Researches: South East of Tehran, Geological Survey of Iran, Geoscience.

Nazari, H., Ritz J.F., Salamati, R., Shahidi, A.R., Habibi, H., Ghorashi, M., Karimi Bavandpur, A.R., 2010, Distinguishing between fault scarps and shorelines: the question of the nature of the Kahrizak, North Rey and south Rey features in Tehran plain (Iran): Terra Nova, v. 00, No.0, pp. 111.

Perdrami, M., 1981, Pasadenian Orogeny and Iranian Geology in Last 700 kyrs. Internal Report (In Persian): Geological Survey of Iran, Tehran, Iran.

Philip, H., Meghraui, M., Feb.1983, Structural Analysis and Interpretation of the surface Deformations of the El ASNAM Earthqauke of October, 10, 1980: Tectonics, v. 2, No. 1, pp. 17-49.

Ritz J.F. - Nazari H., Ghassemi A., Salamati R., Shafei A., Solaymani S., Vernant P., June 2006. Active transtension inside central Alborz: A new insight into northern Iran-southern Caspian geodynamics: Geological Society of America, Geology, v. 34, no. 6, pp. 477-480.

Solaymani Azad, S., Ritz, J.F., Abbassi, M.R., 2011, Left-lateral active deformation along the Mosha-North Tehran fault system (Iran): Morphotectonics and paleoseismological investigations, Tectonophysics, v. 497 , no. 1 , pp.1-14.

Tchalenko, JS, Berberian M, Iranmanesh H, Baily M, Arsovsky M, 1974, Tectonic framework of the Tehran region: Geological Survev of Iran, v. 26, pp.7-46.

Vernant, P., Nilforoushan, F., Hatzfeld D., Abassi M., Vigny C., Masson F., Nankali H., Martinod J., Ghafory-Ashtiany M., Bayer R., Tavakoli F., Che'ry J., 2004, Deciphering oblique shortening of central Alborz in Iran using geodetic data. Earth Planetary Science Letters, v. 223, pp. $177-185$. 